\title{
Semiotic Study in the Muput Tradition from Taraju Village Sindangagung District Kuningan Regency
}

\author{
O Ropiah ${ }^{1, *}$, E Puspitarini ${ }^{1}$ H Triwahyuni ${ }^{1}$ B Agustan ${ }^{2}$, and I Ripai ${ }^{3}$ \\ ${ }^{L}$ Local language and literature education, STKIP Muhammadiyah Kuningan \\ ${ }^{2}$ Health and recreation physical education, STKIP Muhammadiyah Kuningan \\ ${ }^{3}$ Information and communication technology education, STKIP Muhammadiyah Kuningan \\ *corresponding author email: ropiah10@upmk.ac.id
}

\begin{abstract}
This research was conducted because of the fact that many people, especially young people and women, have not preserved the muput tradition. This study aims to describe the implementation of the muput tradition, to analyze the semiotic elements that exist in the Muput tradition. The method used in this research is descriptive. Data collection techniques used in this study were interviews, observation, documentation. The results of this study are the implementation of tradition muput in Taraju Village, Sindangagung District, Kuningan Regency is divided into four, namely: 1) preparation; 2) pray for relatives who have died; 3) the implementation of the muput tradition which consists of 12 activities, and 4) the sawer gives rezeky a sign that the muput tradition is over. The semiotic elements of the muput tradition are: 2 icons, 11 index, and 14 symbols.
\end{abstract}

Keywords: Muput Tradition- Semiotics

\section{INTRODUCTION}

The Sundanese people have a tradition passed down from their ancestors. Tradition is a hereditary habit that exists in society. One of the traditions of the Sundanese people is muput in Taraju Village, Sindangagung District, Kuningan Regency. Muput is a tradition that is carried out when the baby's umbilical cord is released. When holding the muput tradition, there are no definite provisions because it depends on the release of the baby's umbilical cord. The people of Taraju Village, Sindangagung District believe that the implementation of this muput activity can ask for safety for babies who have been born into the world.

In the activity of the muput tradition, there are several stages starting with preparing offerings until the last event of sawer sharing rezeky. The community believes that the activities of muput have a purpose and meaning. The meaning that is in the tardisi muput is called semiotic. Semiotics in question is a science or method of analysis for all signs [1].

The muput tradition is an old tradition, but not all people know about the muput tradition, especially young men and women in Taraju Village, Sindangagung District, Kuningan Regency. This is because the FIGUREs involved in the implementation of the tradition are only parents. So the muput tradition is important for the younger generation to know so that it can be preserved and cultivated as a Sundanese cultural heritage.

The formulation of the problem in this research is formulated on several questions, namely: (1) How is the implementation of the muput tradition in Taraju Village, Sindangagung District, Kuningan Regency?; and (2) The element of any existing semiotic tradition Taraju muput Village, District Sindangagung, Kuningan District?

The purpose of this study is to describe: (1) the implementation of the muput tradition in Taraju Village, Sindangagung District, Kuningan Regency; and (2) Semiotic elements that exist in the muput tradition in Taraju Village, Sindangagung District, Kuningan Regency.

The theoretical benefit of this research is to increase knowledge in the field of Sundanese culture, both formal and informal. The practical benefit is that the community can preserve the muput tradition and can be used as cultural tourism in Kuningan.

Tradition is a habit that exists in society, according to Danadibrata [2] tradition is a custom. According to Sutiyono [3] the traditions are: In general, the tradition of safety in Javanese society is divided into four, namely the safety of the human life cycle consisting of pregnancy safety (Neloni, Mitoni, Procotan), safety of birth (Brokohan, Puputan, dissolution), guarantee of marriage (Midodareni, Sepasaran, Tingkeban), safety of death 
(Surtanah, three days, forty days, one hundred days, one year, two years and thousands). "

Muput is the release of the umbilical cord from the baby's center [4]. According to Hanum [5] "The tradition of Puputan is carried out when the baby's umbilical cord is separated from the navel of the baby. Besides, it also functions to maintain the health of the baby who has been born" which aims for the safety of the baby.

Semiotics can be interpreted as "the science of signs" and then semiotics is further developed into a branch of knowledge that circulates about everything related to signs. Semiotics is a science or method of analysis to look for signs [6]. From the description above, it can be concluded that semiotics is an outstanding science about everything related to signs. According to Pierce [7] a sign as "one thing" represents "one thing", meaning that it is a concrete thing (can be captured by human light), which then goes through a process representing "something" in cognitive comes from everything the senses perceive. According to Hoed [8], "Semiotics is a method of analysis for studying signs". Etymologically derived from the Greek word meaning semeion 'sign', semiotics can be defined as the science of signs and the study of the systems, rules and conventions that allow these signs to have meaning [9].

From some experts, it can be concluded that semiotics is the study and search of sign systems, everything related to signs, how it works for the sign communication process and who shoots the sign. This means that everything in human life is judged from signs, the smallest example in human life is culture, there are many signs or symbols that must be defined in the nature of human reason. In the Sundanese Dictionary [10] a symbol is defined as a symbol or derivation.

According to Pierce [11] distinguishes three kinds of signs according to the nature of the relationship between signs and signs, namely icons, index, and symbols.

- Icon

Icons are signs that give the impression, such as equality. That is, an icon signifies a symbol that has similarities with the potential thing, one example is a picture, portp, a person's portrait (marker) will have similarities with the original person (marker), especially in something that can be seen with the naked eye.

- Index

Index is a sign that shows a causal relationship (cause and effect). An example is that there are no ants if there is no sugar, ants are the index of sugar because the presence of ants comes from the presence of sugar.

- Symbol
Symbol is a sign whose relationship between a sign and its denotatum is determined by a general rule for those who use the symbol. One of them is the word "mamah" which is a symbol of women who have nurtured and given birth to the world's biological children. It is a symbol used by the people, whereas in English it is the word "mother".

\section{RESEARCH METHOD}

The method used in this research is descriptive method because the research describes the course of the muput tradition and the semiotic elements that exist in the muput tradition. So this study uses a qualitative descriptive analysis method.

According to Meleong [12], the main source of data in qualitative research is the presentation of spoken or written words that are observed to get the implied meaning in the document or object. Sources of data in this study are subjects that can be used to obtain data. Sources of data that can be used in this study are Sembu and the entire community of Taraju Village, Sindangagung District, Kuningan Regency.

According Sugiyono [13] data collection technique is the most important step in the research, because the main purpose of research is to obtain data. The data collection technique has four types of techniques, namely:

1. The observation technique is used to collect data on Muput traditional practices, symbols that appear in the Muput tradition, icons in the Muput tradition and indexes in the Muput tradition.

2. The interview technique is one of the dialogues conducted by the interviewer (interviewer) to get information from the person being interviewed. This interview technique was used to obtain oral (oral) data from Sembu or the Muput traditional elders and the people of Taraju Village.

3. Documentation techniques are used to document how research practice is, and to document what is being investigated from start to finish.

4. Literature review technique is a technique of collecting written materials to find and determine the theoretical basis of objects.

According to [14] research instruments are research tools used to obtain, collect data as a way to obtain results and draw conclusions from the research conducted. The instrument used in this study was an interview guide. 
3. FINDINGS AND DISCUSSION

3.1 Implementation of the Muput
Tradition in Désa Taraju,
Sindangagung District, Kuningan
Regency

The implementation of the muput tradition is divided into four activities, namely panyuguh preparation, ngujuban, core activity, and sawer.

\subsubsection{Preparation panyuguh}

Panyuguh preparation is the activity of preparing small meals consisting of cara beureumi, cara bodas, lauk asin (ikan asin), kupat keupeul, leupeut, and tangtang angin. Panyuguh has a function to send (ngajangan) sodara which is called "sadulur opat lima pancer", namely amniotic fluid, navel, blood, babies and mother babies called pancer or fifth. After that this panyuguh is stored on top of Bali which has been buried in front of the house.

\subsubsection{Ngujuban}

Ngujuban, namely praying for relatives who have died and asking that the muput tradition for babies and their mothers be given smoothness to completion.

\subsubsection{Core activities}

The core activities in the muput tradition consist of 12 activities, namely:

- Babies are immortalized by sembu Ucu.

Sembu Ucu bathes the baby with coconut water and seven kinds of flowers. The benefit is to refresh the baby and smell good.

\section{- Babies digarang}

Sembu ucu warms the baby with charcoal smoke containing iron powder. The benefit is to warm the body of the baby who has been bathed.

- The baby's mother is digarang

The mother of the baby is warmed by covering her entire body with a cloth to sweat it out. The benefit is to refresh the mother of a baby who has given birth.

- The baby is given a necklace

Sembu ucu wears a necklace of red, white, green and black threads to the neck, arms and stomach of the baby. This activity means that when the baby grows up, he will have a lot of treasure and gold.

\section{- $\quad$ Baby get dressed}

Sembu Ucu dresses the baby by applying lipstick to the lips and an eyebrow pencil for the eyebrows. The meaning of making up a baby is to be beautiful and handsome and have lots of love.

- The baby was digebrag

Babies are pounded using a tap that is tapped under the mattress on the right, left, top, and bottom of the sleeping baby. This means that babies obey their parents.

- The baby gets scratched by the chicken
The baby's feet are scratched by chickens so they can find work and be diligent in looking for sustenance.

- Panebus baby

The baby redeemer is the activity of giving money, coconuts, and rice in return for killing the baby to

- $\quad$ Baby cradled

Babies are swung using swings made of rattan. On the swing hang the clothes of the father and mother, a bowl, and a mukena. Sembu Ucu prayed while singing the baby on a swing with a kajawen prayer "Get to know Saturene not Nana with people who worship the natural form of la ilaha illallah wa asyhadu anna muhammad rasulullah". The hope of the Sembu ucu prayer is that the baby who has been given a name will become a child who is obedient to his parents and obey the teachings of his religion.

- Upah Inum

Sembu Ucu gave a concoction called "wages inum" consisting of pepper root, yeast, coconut water, and brown sugar to prevent a bloated stomach after giving birth and drunk near the door so you don't get pregnant again quickly.

- The baby's mother is ensured

Baby mother dipeureuh is the activity of dripping lime juice into the mother's eye so that her eyes are fresh after childbirth.

- $\quad$ Eat together

The mother and father of the baby eat together with small portions of food, which means that they live in harmony and last until death does.

3.1.4. Sawer

The family prepares saweran consisting of rice, candy, and money. The sawer activity has completed the muput tradition for babies.

\subsection{Semiotic Elements in the Muput Tradition in Taraju Village, Sindangagung District, Kuningan Regency}

The semiotic elements contained in the muput tradition are seen from the sequence of events, food, and equipment. The study of semiotics used based on Pierce's theory includes icons, indices and symbols.

- Icons

The icons in the muput tradition are composed of two icons, namely grilling (grill) and parukuyan.

a. charcoal (grill) is a medium used to warm babies and their mothers in the Muput tradition.

b. Parupuyan is a fragrance which symbolizes a means of relating to the supernatural or a means of communication with ancestors.

- Index

a. Muput tradition, is one of the traditions held in the care of newborns.

b. Panyuguh, is a requirement in the muput tradition to send food to the five pancer sadulur opat. 
c. The swing is called an index because if it is not swung, it will not swing.

d. Fragrant parupuyan to refuse reinforcements.

e. The smell of coffee is called an index because if no one brewed the coffee, there would be no smell of coffee.

f. The smell of tea will not be smelled if no one makes tea.

g. Coconut leaves are called index because of the ingredients for making leupeut that are in the panyuguh.

h. Bamboo leaves are called indexes because they are the material for making wind rods.

i. The voice praying is called an index because if no one prayed it would not be heard.

j. Flower water is called index because if there is no flower water it will not smell good.

k. Jambe mayang flower is called an index because if it is not provided, it will not smell like jambe flowers.

- Symbol

a. The umbilical cord, the breaking of the baby's umbilical cord in all traditions indicates that the baby is ready for puput.

b. Congcot is white rice that is shaped like smoke or a mountain that is taller and more radiant. Congcot has a symbol that represents human life that will return to its origin and holiness that connects heaven and earth. Since ancient times it has been used for the diet of all human beings in nature, and is the main source of human diet.

c. The bodas way and the beureum way are corabi types but are small in size. In addition to the bodas method and the beureum method, beureum porridge and bodas porridge are always used, which means a symbol of appetite. The beureum way symbolizes the male appetite or courage and the bodas way symbolizes the female appetite or chastity.

d. Kupat keupeul wrapped in woven coconut leaves and octagonal shape. In the context of sacrifice, the grip has a meaning or symbolic circle of determination.

e. Tangtang Angin is made from ordinary rice or glutinous rice wrapped in triangular bamboo leaves. In terms of presentation, the wind has a triangular symbol, namely speech, determination, and action.

f. Leupeut, made of rice wrapped in coconut leaves about $5 \mathrm{~cm}$ long and tied with a rope made of bamboo (hinis). In terms of terms, the leupeut has a long symbol of forgiveness.

g. Clear water, is plain water that is always used for drinking. Clear water is called a symbol because it symbolizes life.

h. Coffee water is sweet and bitter. Bitter coffee water is called bitter because it does not use sugar and sweet coffee water is called sweet because it uses sugar. Sweet and bitter coffee water symbolizes that in life there is bitter and there is sweet. So we have to be ready whether it's sweet or bitter.

i. Sweet tea water and bitter tea water. bitter tea water is called bitter because it does not use sugar while sweet tea water uses sugar. Sweet tea water and bitter tea water have one of the characteristics that exist in humans, meaning that humans must always be in a simple state in facing certain lives.

j. Seven kinds of flowers are tools used to bathe babies combined with young coconut water, warm water. Seven kinds of flowers contain symbols of seven meanings, namely life, strength, sight, hearing, speech, feelings and desire.

k. Salted fish in cooking has a symbol in life that it is not all sweet but there is also a pleasant hard life.

1. Salted eggs, are a necessity as a whole and have a symbol of life that gives fertility and long life. The symbol on the egg symbolizes life in nature because the yellow part of the egg symbolizes worldliness and the white color of the egg is purity.

m. Brown sugar tastes sweet. Brown sugar is called a symbol because it symbolizes respect for the ancestors and brown sugar is the most preferred by the ancestors.

n. Parupuyan is a fragrance that symbolizes a tool to connect with the supernatural to communicate with ancestors.

\section{CONCLUSION}

The conclusion of this research is implementation in the muput tradition in Désa Taraju, Sindangagung District, Kuningan District is divided into four, namely 1) preparing panyuguh; 2) ngujuban; 3) the core activities of the muput tradition which include 12 activities, namely babies being enshrined by Ucu, babies being bruised, mothers babies being bruised, babies given necklaces, babies dressed up, babies shredded, babies scratched by chickens, baby panebus, baby cradled, inum wages, mother babies be sure, and eat together; and 4) sawer share sustenance. Sémiotic elements in the Muput Tradition in Désa Taraju, Sindangagung District, Kuningan Regency, namely 2 icons, namely grill and parupuyan; 11 indéks, namely the traditions of muput, panyuguh, gagayungan, parupuyan fragrance, coffee aroma, tea fragrance, coconut leaves, bamboo leaves, praying voices, flower water, 
and mayang jambe flowers; and 14 symbols, namely the umbilical cord, congcot, bodas way and beureum method, kupat keupeul, wind tangtang, leupeut, clear water, sweet and bitter coffee water, sweet tea water and bitter tea water, seven kinds of flowers, salted fish, salted eggs, brown sugar and parupuyan.

\section{ACKNOWLEDGMENTS}

1. Chairperson of the STKIP Muhammadiyah Kuningan, Nanan Abdul Manan, M.Pd, who has supported this research activity.

2. Institute for Research and Community Service STKIP Muhammadiyah Kuningan.

3. Beloved family who has provided motivation.

4. Research member who helped with this research.

5. All parties involved in this research.

\section{REFERENCES}

[1] Sobur, Semiotika Komunikasi, Bandung: PT Remaja Rosdakarya, 2016, p. 15.

[2] R. Danadibrata, Kamus Besar Basa Sunda, Bandung: PT Kiblat Buku Utama, 2006, p. 710.

[3] F. Putri, R. M. Sinaga and M. Basri, "Makna Material Tradisi Puputan pada Masyarakat Jawa di Kampung Rukhti Harjo," PESAGI (Jurnal Pendidikan dan Penelitian Sejarah), vol. 7, no. 1, pp. 1-12, 2019.

[4] Rosidi, Ensiklopedi Sunda Alam, Manusa, dan Budaya Termasuk Budaya Cirebon dan Betawi, Jakarta: Pustaka Jaya, 2000, p. 527.

[5] Sobur, Semiotika Komunikasi, Bandung: PT Remaja Rosdakarya, 2016, p. 3.

[6] Sobur, Semiotika Komunikasi, Bandung: PT Remaja Rosdakarya, 2016, p. 15.

[7] Sobur, Semiotika Komunikasi, Bandung: PT Remaj rosdakarya, 2016, p. 41.

[8] H. Hoed, Semiotika \& Dinamika Sosial Budaya, Depok: Komunitas Bambu, 2014, p. 55.

[9] U. Yunus and D. Tulasi, "Batik Semiotics as a Media of Communication in Java," Cultura International Journal of Philosophy of Culture and Axiologi, vol. 9, no. 2, pp. 143-150, 2012.

[10] Danadibrata, Kamus Besar Basa Sunda, Bandung: PT Kiblat Buku Utama, 2006, p. 639.

[11] Sobur, Semiotika Komunikasi, Bandung: PT Remaja Rosdakarya, 2016, p. 40.

[12] S. Arikunto, Prosedur Penelitian Suatu Pendekatan Praktek, Jakarta: Rineka Cipta, 2013, p. 22.

[13] Sugiyono, Metode Penelitian Pendidikan Pendekatan Kualitatif $\mathrm{R}$ \& D, Bandung: Alfabeta, 2010, p. 240.

[14] Sugiyono, Metode Penelitian Pendidikan Pendekatan Kualitatif R \& D, Bandung: Alfabeta, 2016, p. 222 